\title{
Enteric neuronal plasticity and a reduced number of interstitial cells of Cajal in hypertrophic rat ileum
}

E Ekblad, R Sjuve, A Arner, F Sundler

\begin{abstract}
Background-Partial obstruction of the ileum causes a notable hypertrophy of smooth muscle cells and enteric neurones in the proximally located intestine.

Aims-To study the expression of neuromessengers in the hypertrophic ileum of rat as little is known about neuromessenger plasticity under these conditions. To investigate the presence of interstitial cells of Cajal (ICC) in hypertrophic ileum. Methods-Ileal hypertrophy was induced by circumferential application of a strip of plastic film for 18-24 days. Immunocytochemistry, in situ hybridisation, nicotinamide adenine dinucleotide phosphate (NADPH) diaphorase histochemistry, and ethidium bromide staining were used to investigate the number of enteric neurones expressing neuropeptides and nitric oxide synthase, and the frequency of ICC. Results-In the hypertrophic ileum several neuronal populations showed changes in their expression of neuromessengers. Myenteric neurones expressing vasoactive intestinal peptide (VIP), pituitary adenylate cyclase activating peptide, and galanin were notably increased in number. In submucous ganglia the number of VIP immunoreactive neurones decreased while those expressing VIP mRNA increased. NADPH diaphorase positive submucous neurones increased dramatically while the number of neuronal type nitric oxide synthase expressing ones was unchanged. The number of ICC decreased notably in hypertrophic ileum. Conclusion-Enteric neurones change their levels of expression of neuromessengers in hypertrophic ileum. ICC are also affected. The changes are presumably part of an adaptive response to the increased work load.

(Gut 1998;42:836-844)
\end{abstract}

Keywords: enteric nerves; interstitial cells of Cajal; hypertrophy; neuropeptides; nitric oxide; neuronal plasticity

A Arner

F Sundler

Correspondence to:

Dr E Ekblad, Department of

Physiology and

Neuroscience, Section of

Neuroendocrine Cell

Biology, University of Lund,

Lund University Hospital,

E-blocket vån $5, \mathrm{~S}-22185$

Lund, Sweden.

Accepted for publication 19 January 1998 submucous and the myenteric, collectively referred to as the enteric nervous system (ENS). The enteric neurones are multimessenger systems with a whole range of signalling molecules from regular neurotransmitters and nitric oxide to neuropeptides and growth factors (for reviews see Ekblad et al, ${ }^{1}$ Podolsky, ${ }^{2}$ and Furness $\left.e t a l^{3}\right)$. Gastrointestinal activities are to a great extent mediated by intramural nerve reflexes that are independent of input from the central nervous system (for a review see $\left.\mathrm{Wood}^{4}\right)$. The basic cellular requirements for integrative circuits (sensory neurones, interneurones, and secretomotor neurones) are thought to be present within the enteric ganglia (for a review see Gershon $e t a \bar{P}$ ). In addition to enteric neurones the gastrointestinal tract also harbours interstitial cells of Cajal (ICC), mainly situated in the deep muscular plexus and the myenteric ganglia but found also within the smooth muscle layers. ICC have been suggested to act as pacemaker and transducer cells as they generate the spontaneous slow waves of the smooth muscle, facilitate active propagation of excitation, and mediate neurotransmission (for reviews see Kobayashi ${ }^{6}$ and Sanders ${ }^{7}$ ). ICC can be detected by immunocytochemistry using antibodies to the c-kit receptor. ${ }^{8}$

Changes in the expression of neurotransmitters have been found to occur in peripheral (including enteric) neurones after axonal damage or transport blockade. ${ }^{9-11}$ Thus, colchicine treatment and axotomy have been found to cause a notable up regulation of vasoactive intestinal peptide (VIP) expression in enteric neurones in rat small intestine while the expression of neuropeptide Y (NPY) and neuronal type nitric oxide synthase (nNOS) was unaffected. ${ }^{11}$

Partial obstruction of the small intestine of rat, guinea pig, and dog results in a notable hypertrophy of the intestinal wall due to thickening of the smooth muscle layer, particularly the inner circular one, and an increased diameter, but an unchanged length, of the proximally located intestine. ${ }^{12-15}$ The increase in smooth muscle is accounted for by both an increase in size and in the number of smooth muscle cells. The size of neurones in the enteric ganglia is also increased in the hypertrophic segment. The number of neurones within the ganglia is unchanged whereas the density is lower in hypertrophic ileum compared with control. In guinea pig control ileum the volume of the myenteric ganglia constitutes approximately $3 \%$ of the muscle volume while in hypertrophic ileum it is only $0.6 \%$ due to the vast increase in the smooth muscle volume. ${ }^{16} \mathrm{~A}$ twofold increase in the average area of myenteric neuronal profiles was reported. Approximately $50 \%$ of all myenteric nerve cell 
bodies measured more than $500 \mu \mathrm{m}^{2}$ compared with less than $3 \%$ in control intestine. A notable increase in average neuronal size was also shown in submucous neurones. ${ }^{16}$ Myenteric neurones sometimes reached $2000 \mu \mathrm{m}^{2}$ in profile area while submucous neurones never exceeded $1000 \mu^{2}$. An increase in size of nerve cells in the dorsal root ganglia projecting to the ileum has been reported after hypertrophy due to partial intestinal obstruction in the rat. ${ }^{17}$

Apart from one report indicating an increased number and staining intensity of VIP immunoreactive myenteric neurones in hypertrophic ileum, ${ }^{18}$ no information on the expression of neurotransmitters in the enteric neurones after hypertrophy of the intestine is available. Furthermore, the way the ICC react in hypertrophic intestine is unknown.

Understanding of the adaptive processes in the nervous components and pacemaker cells in response to intestinal growth, may provide information on their roles in regulating intestinal motility. The aims of the present study were to compare the expression of several neuropeptides and neurotransmitters in enteric neurones using immunocytochemistry, nicotinamide adenine dinucleotide phosphate (NADPH) diaphorase histochemistry, and in situ hybridisation in control and hypertrophic ileum from adult rats in order to reveal possible changes in the neuromessenger expression of these neurones following growth due to partial obstruction. Furthermore, the occurrence and distribution of ICC, using c-kit receptor antibodies, in control and in hypertrophic ileum were examined.

\section{Materials and methods}

ANIMALS, SURGICAL PROCEDURES, AND TISSUE PROCESSING.

Adult female Spraque-Dawley rats (240-260 g) were used. Partial obstruction of the ileum was performed in 10 rats using a technique modified from Gabella. ${ }^{16}$ The rats were anaesthetised using ketamine (Ketalar, $100 \mathrm{mg} / \mathrm{kg}$ ) and xylazine (Rompun, $15 \mathrm{mg} / \mathrm{kg}$ ). Via an abdominal incision, a loop of ileum approximately $5 \mathrm{~cm}$ from the ileocaecal junction was exposed and a small cut in the mesentery as close as possible to the gut was performed. A strip of plastic film (material for overhead presentations, width $6 \mathrm{~mm}$ ) was fixed around the intestine and closed with silk. The diameter of the ring was $1-2 \mathrm{~mm}$ wider than the intestine, leaving the ring free to turn. Operated rats were housed individually with free access to standard rat chow and water. Postoperatively the animals were monitored daily with regard to weight, general well being, and circumference of the abdomen. Rats subjected to partial obstruction were killed 18-24 days postoperatively. Proximal to the obstruction the small intestine was greatly distended with an increased wall thickness. The hypertrophy was most pronounced $6-7 \mathrm{~cm}$ proximal to the obstruction; a gradual transition to normal occurred further proximally and in midjejunum a normal appearance of the intestinal wall was noted. The distal ileum from age matched controls $(n=6)$ and operated rats was opened along the mesenteric border and pinned flat, without stretching, on pieces of balsa wood. In operated rats the specimens were taken immediately proximal to the ring. The specimens were fixed overnight in a mixture of $2 \%$ formaldehyde and $0.2 \%$ picric acid in phosphate buffer ( $\mathrm{pH}$ 7.2) followed by thorough rinsing in Tyrode's solution containing $10 \%$ sucrose. Whole wall specimens, approximately $10 \mathrm{~mm}$ long, were then frozen on dry ice and cut in a cryostat to a thickness of $10 \mu \mathrm{m}$. Sections were placed on chrome alum coated slides and processed for NADPH diaphorase histochemistry, immunocytochemistry, in situ hybridisation, or ethidium bromide staining. The procedures were approved by the Animal Ethics Committee, Lund University.

\section{IMMUNOCYTOCHEMISTRY}

Previously characterised nNOS, NPY, VIP, substance P (SP), galanin, pituitary adenylate cyclase activating peptide (PACAP), calcitonin gene related peptide (CGRP), and gastrin releasing peptide (GRP) antisera raised in rabbits (table 1 ) were used to identify the various neuronal populations. ICC were identified using an affinity purified polyclonal rabbit antiserum raised against a synthetic peptide corresponding to amino acid residues 958-976 within the $\mathrm{C}$ terminal domain of the human c-kit receptor (Santa Cruz Biotechnology, Santa Cruz, California, USA). The antiserum is known to cross react with the tyrosine kinase receptor, c-kit, expressed by ICC. ${ }^{23}$ The site of the antigen-antibody reaction was visualised by fluorescein isothiocyanate conjugated antibodies to rabbit IgG raised in pigs (Dako, Copenhagen, Denmark). For controls, antisera (except the c-kit receptor antibodies) that had been inactivated by the addition of an excess amount of antigen (10-100 $\mu \mathrm{g}$ of synthetic peptide per $\mathrm{ml}$ diluted antiserum) were used. In addition each peptide antibody was tested for cross reactivity with the other peptides examined. Cross reactivity with other peptides

Table 1 Details of antisera

\begin{tabular}{|c|c|c|c|c|c|}
\hline Antigen & Code & Raised against & $\begin{array}{l}\text { Working } \\
\text { dilution }\end{array}$ & Source & Reference \\
\hline CGRP & 8427 & Synthetic CGRP & 1 in 320 & Euro-Diagnostica AB, Malmö, Sweden & 19 \\
\hline Galanin & 8416 & Synthetic porcine galanin & 1 in 320 & Euro-Diagnostica $\mathrm{AB}$ & 20 \\
\hline GRP & R-6902 & Synthetic porcine GRP & 1 in 320 & Professor N Yanaihara, Shizouka, Japan & 20 \\
\hline nNOS & 9223 & $\begin{array}{l}\text { Synthetic C term fragment of } \\
\text { rat cerebellar NOS }\end{array}$ & 1 in 1280 & Euro-Diagnostica AB & 21 \\
\hline NPY & 8404 & Synthetic porcine NPY & 1 in 320 & Euro-Diagnostica AB & 19 \\
\hline PACAP & $88121-3$ & Pure ovine PACAP-27 & 1 in 640 & Professor A Arimura, Lousiana, USA & 22 \\
\hline SP & SP8 & Synthetic bovine SP & 1 in 320 & Professor PC Emson, Cambridge, UK & 19 \\
\hline VIP & 7852 & Natural porcine VIP & 1 in 640 & Euro-Diagnostica AB & 19 \\
\hline
\end{tabular}


or proteins cannot be excluded. It is appropriate, therefore, to refer to the immunoreactive material as VIP-like, NPY-like and so on. For simplicity, however, the shorter terms are used in the following.

IN SITU HYBRIDISATION

For the detection of nNOS mRNA, a 30 mer oligodeoxyribonucleotide probe complementary to the sequence 77-106 of rat cerebellar NOS mRNA ${ }^{24}$ was used (Biomolecular Re- source Facility, University of Lund, Sweden). For the detection of VIP mRNA a 29 mer oligoprobe complementary to nucleotides 347375 in rat VIP mRNA $^{25}$ was used (Du Pont Scandinavia AB, Sweden). NPY mRNA was detected using a 36 mer oligoprobe complementary to nucleotides $266-301$ in rat NPY mRNA $^{26}$ (Biomolecular Resource Facility). Galanin mRNA was detected using a 30 mer oligoprobe complementary to nucleotides $275-304$ in rat galanin $\mathrm{mRNA}^{27}$ (Biomolecular
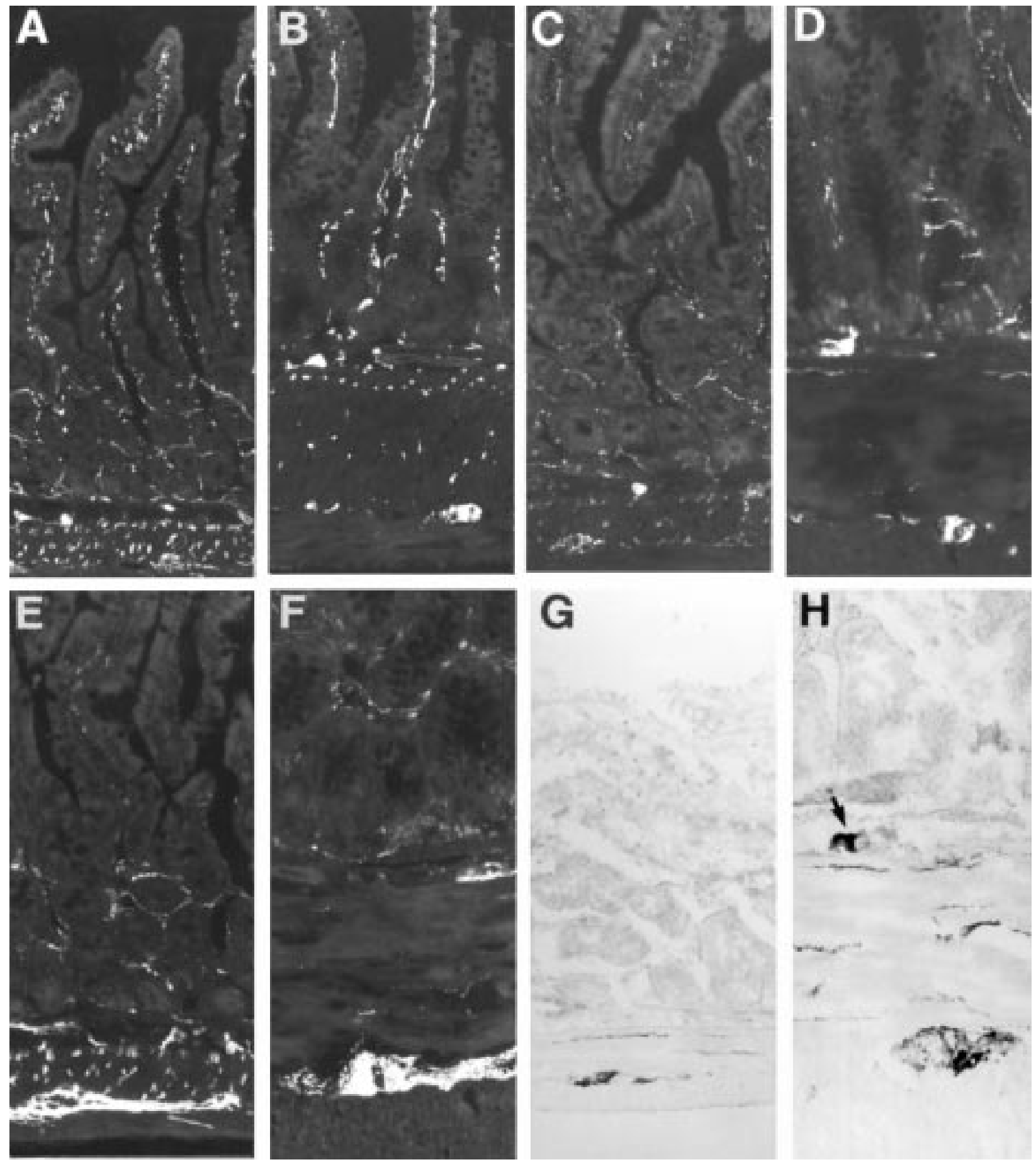

Figure 1 Cryostat sections from rat: control $(A, C, E, G)$ and hypertrophic (B,D,F,H) ileum, immunostained for VIP $(A, B), P A C A P(C, D)$, and galanin $(E, F)$ or NADPH diaphorase stained $(G, H)$. The notable thickening of the smooth muscle layers in hypertrophic ileum and the decreased frequency of nerve fibres in these lavers are obvious. The size of the neuronal cell bodies is increased in hypertrophic ileum. Note in (H) a large NADPH diaphorase positive nerve cell body within the submucosal ganglion (arrow); such cell bodies are commonly seen in hypertrophic ileum but are extremely rare in control tissue. Original magnification $\times 130$. 
Resource Facility, University of Lund, Sweden). The NOS, VIP, and NPY mRNA probes have previously been used for in situ hybridisation on enteric neurones. ${ }^{11}$ The probes were $3^{\prime}$ endtailed with ${ }^{35} \mathrm{~S}$-dATP by use of terminal transferase (both supplied by NEN, DuPont, Stockholm, Sweden), yielding a specific activity of approximately $2 \times 10^{9} \mathrm{cpm} / \mu \mathrm{g}$. The hybridisation protocol has previously been described in detail. ${ }^{28}$ Briefly, after clearing in chloroform, the sections were acetylated and hybridised with the probes $(1 \mathrm{pmol} / \mathrm{ml})$ overnight at $37^{\circ} \mathrm{C}$. The slides were washed $(1 \times$ SSC, $4 \times 15$ minutes, $55^{\circ} \mathrm{C}$ ), dehydrated, and dipped in emulsion (Ilford K5). Exposure times ranged between three and four weeks after which the slides were developed in Kodak D-19. For control purposes, hybridisation was also performed after incubation in RNAse A $(45 \mu \mathrm{g} / \mathrm{ml}$, Sigma, St Louis, Missouri, USA; 30 minutes at $37^{\circ} \mathrm{C}$ ) or in the presence of a 100 -fold excess of unlabelled probe in the hybridisation buffer. In the control experiments, autoradiographic labelling of enteric neurones was not obtained.
NADPH DIAPHORASE HISTOCHEMISTRY

NADPH diaphorase activity was rendered visible by incubation of cryostat sections for 45 minutes in $0.1 \mathrm{M}$ Tris- $\mathrm{HCl}(\mathrm{pH}$ 7.2) containing $1 \mathrm{mM}$ NADPH (Sigma, St Louis, Missouri, USA), $0.2 \%$ Triton $\mathrm{X}-100$ at $37^{\circ} \mathrm{C}$, followed by washing in Tris- $\mathrm{HCl}$ (modified from Hope $e t a l^{9}$ ).

ETHIDIUM BROMIDE STAINING

Counter staining using $0.1 \%$ of ethidium bromide in Tris- $\mathrm{HCl}$ was used in order to visualise all nerve cell bodies. ${ }^{30}$

CELL COUNTING

Immunoreactive, NADPH positive, ethidium bromide stained or autoradiographically labelled (mRNA containing) nerve cell bodies in submucous and myenteric ganglia were counted per visual field $(1.2 \mathrm{~mm})$ in longitudinally cut whole wall sections from control $(n=6)$ and hypertrophic $(n=10)$ ileum. Each section was approximately $10 \mathrm{~mm}$ long and from each animal three sections cut at different
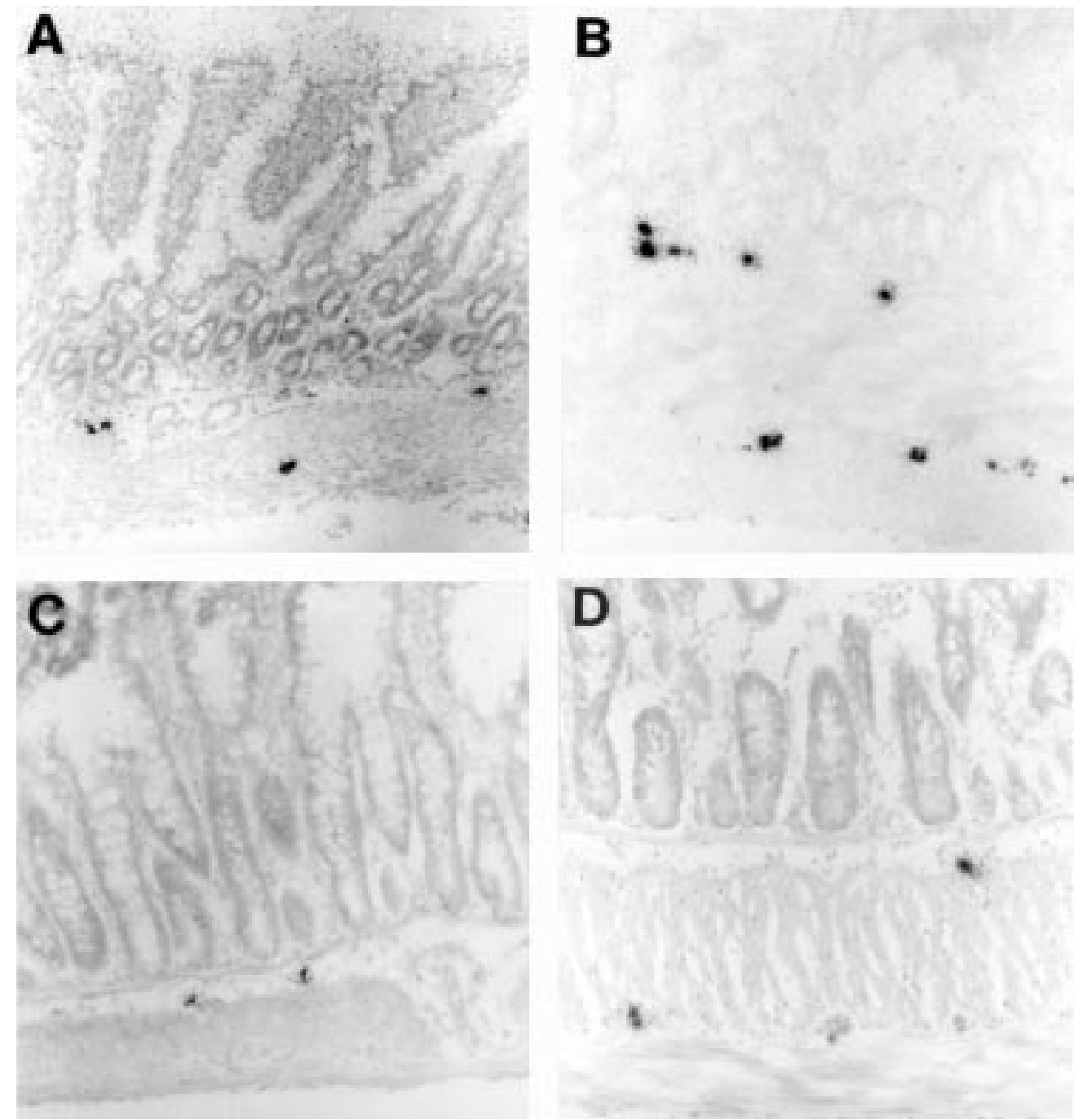

Figure 2 Cryostat sections from rat: control $(A, C)$ and hypertrophic $(B, D)$ ileum autoradiographically labelled for VIP $m R N A(A, B)$ and galanin $m R N A(C, D)$. VIP $m R N A$ containing nerve cell bodies are larger, more numerous, and more intensely labelled in hypertrophic ileum. The number of galanin mRNA containing nerve cell bodies is particularly increased in the myenteric ganglia where they are larger and more intensely labelled. Original magnification $\times 130$. 
Table 2 Numbers per visual field of immunoreactive, mRNA labelled, NADPH diaphorase positive and ethidium bromide stained submucosal neurones in control and hypertrophic ileum

\begin{tabular}{|c|c|c|c|c|c|c|}
\hline & \multicolumn{2}{|l|}{ Immunoreactive } & \multicolumn{2}{|l|}{$m R N A$ labelled } & \multicolumn{2}{|c|}{ NADPH diaphorase positive } \\
\hline & Control & Hypertrophy & Control & Hypertrophy & Control & Hypertrophy \\
\hline VIP & $1.87(0.12)(211)$ & $0.91(0.05)(379)$ & $1.69(0.10)(179)$ & $1.68(0.08)(253)$ & $0.12(0.03)(241)$ & $1.10(0.06)(610)$ \\
\hline PACAP & $0.73(0.06)(194)$ & $0.60(0.04)(376)$ & & & & \\
\hline Galanin & $0.38(0.05)(222)$ & $0.24(0.03)(388)$ & $0.34(0.08)(61)$ & $0.58(0.07)(117)$ & \multicolumn{2}{|c|}{ Ethidium bromide stained } \\
\hline GRP & $0.07(0.02)(115)$ & $0.04(0.01)(236)$ & & & & \\
\hline SP & $0.05(0.03)(60)$ & $0.04(0.02)(96)$ & & & Control & Hypertrophy \\
\hline CGRP & $0.27(0.06)(58)$ & $0.10(0.03)(100)$ & & & $4.20(0.26)(106)$ & \\
\hline NPY & $1.71(0.09)(199)$ & $1.01(0.05)(428)$ & $1.43(0.08)(60)$ & $0.89(0.09)(112)$ & $4.20(0.26)(106)$ & $2.61(0.14)(231)$ \\
\hline nNOS & $0.10(0.02)(220)$ & $0.12(0.02)(269)$ & $0.07(0.02)(163)$ & $0.05(0.02)(240)$ & & \\
\hline
\end{tabular}

Results are expressed as mean (SEM) (n).

depths were analysed. Longitudinally cut sections were used as the length of the hypertrophic segment has been reported to be unchanged. ${ }^{14}$ Statistical evaluation was by Student's $t$ test.

\section{Results}

In rats with obstruction there was notable hypertrophy of both the smooth muscle layer (approximately 10 times thicker) and of enteric nerve cell bodies in the proximally located segment of the ileum. With the exception of the c-kit antiserum, a marker for ICC, all antibodies used identified immunoreactive nerve fibres and cell bodies in both control and hypertrophic intestine. Figure $1 \mathrm{~A}-\mathrm{F}$ illustrates the VIP, PACAP, and galanin containing neuronal populations. Using in situ hybridisation, neuronal cell bodies were found to contain VIP (fig 2A,B), galanin (fig 2C,D), NPY, and nNOS mRNA.

The distribution pattern of nerve fibres in control ileum was as previously described. ${ }^{19}{ }^{21} 22$ Numerous VIP (fig 1A), NPY, galanin (fig $1 \mathrm{E}$ ), and $\mathrm{SP}$ containing nerve fibres were found in all layers of the ileal wall, while PACAP (fig 1C), CGRP, and GRP containing ones were slightly less frequent. NADPH diaphorase postive (fig $1 \mathrm{G}$ ) and nNOS immunoreactive nerve fibres were almost exclusively found within the smooth muscle, particularly the deep muscular plexus, and in myenteric ganglia, where they were numerous. The topographic distribution of the various nerve fibre populations in hypertrophic ileum was identical to that of the control although the number of the various nerve fibres was slightly reduced, particularly within the smooth muscle (fig 1), probably reflecting an increased diameter of the ileum and thickening of its smooth muscle layers. Cell counting revealed that the total numbers of both submucous and myenteric neurones per unit length were reduced in the hypertrophic ileum (tables 2 and 3 ). In order to facilitate comparison between control and hypertrophic ileum the number of cell bodies in each of the different neuronal populations will, in the following, be referred to as percentage of the total number of cell bodies. Tables 2 and 3 present the numbers of cell bodies (submucous and myenteric) per unit length of each neuronal population.

In submucosal ganglia of control ileum nerve cell bodies containing immunoreactive VIP or NPY were the most frequent (more than 40\% of total), followed by cell bodies containing PACAP, galanin, or CGRP (6-18\% of total). SP, GRP, and NOS immunoreactive cell bodies were rare $(1-2 \%$ of total) (fig $3 \mathrm{~A}$ ). On the whole, in situ hybridisation for VIP, NPY, galanin, and nNOS mRNA gave similar results showing VIP and NPY mRNA in $40 \%$ and $34 \%$, respectively, of the total number of submucosal cell bodies; galanin mRNA was expressed in $8 \%$ and nNOS in $2 \%$ of all submucosal cell bodies (fig 3B). In hypertrophic ileum the percentage of VIP immunoreactive cell bodies decreased (to $35 \%$ of total) (fig 3A) whereas the number of VIP mRNA expressing submucosal neurones increased notably (to $64 \%$ of total) (figs $2 \mathrm{~B}$ and $3 \mathrm{~B}$ ). A slight increase was also noted in neurones immunoreactive to PACAP (fig 3A). The remainder of the neuronal populations showed no obvious changes in their number as shown by immunocytochemistry (fig 3A). By in situ hybridisation the percentage of submucosal neurones expressing galanin mRNA increased from $8 \%$ in control to $22 \%$ after obstruction (fig 3B). It was remarkable that the percentages of both nNOS immunoreactive (fig $3 \mathrm{~A}$ ) and nNOS mRNA expressing (fig 3B) submucosal neurones were the same as in the control whereas the percentage of cell bodies stained

Table 3 Numbers per visual field of immunoreactive, $m R N A$ labelled, NADPH diaphorase positive and ethidium bromide stained myenteric neurones in control and hypertrophic ileum

\begin{tabular}{|c|c|c|c|c|c|c|}
\hline & \multicolumn{2}{|l|}{ Immunoreactive } & \multicolumn{2}{|l|}{$m R N A$ labelled } & \multicolumn{2}{|c|}{ NADPH diaphorase positive } \\
\hline & Control & Hypertrophy & Control & Hypertrophy & Control & Hypertrophy \\
\hline VIP & $0.11(0.03)(200)$ & $0.50(0.04)(379)$ & $0.22(0.04)(179)$ & $1.58(0.09)(253)$ & $1.87(0.11)(239)$ & $1.46(0.08)(343)$ \\
\hline PACAP & $0.07(0.02)(194)$ & $0.27(0.03)(376)$ & & & & \\
\hline Galanin & $0.23(0.03)(222)$ & $0.50(0.04)(388)$ & $0.29(0.07)(61)$ & $1.57(0.12)(117)$ & \multicolumn{2}{|c|}{ Ethidium bromide stained } \\
\hline GRP & $0.10(0.03)(112)$ & $0.17(0.03)(236)$ & & & & \\
\hline SP & $0.10(0.03)(58)$ & $0.22(0.05)(96)$ & & & Control & Hypertrophy \\
\hline CGRP & $0.19(0.05)(56)$ & $0.36(0.06)(100)$ & & & & \\
\hline NPY & $0.11(0.02)(199)$ & $0.14(0.02)(428)$ & $0.10(0.03)(60)$ & $0.18(0.04)(112)$ & $4.21(0.33)(106)$ & $3.45(0.20)(231)$ \\
\hline nNOS & $1.75(0.11)(220)$ & $1.48(0.10)(269)$ & $1.17(0.10)(163)$ & $1.14(0.08)(240)$ & & \\
\hline
\end{tabular}

Results are expressed as mean (SEM) (n). 

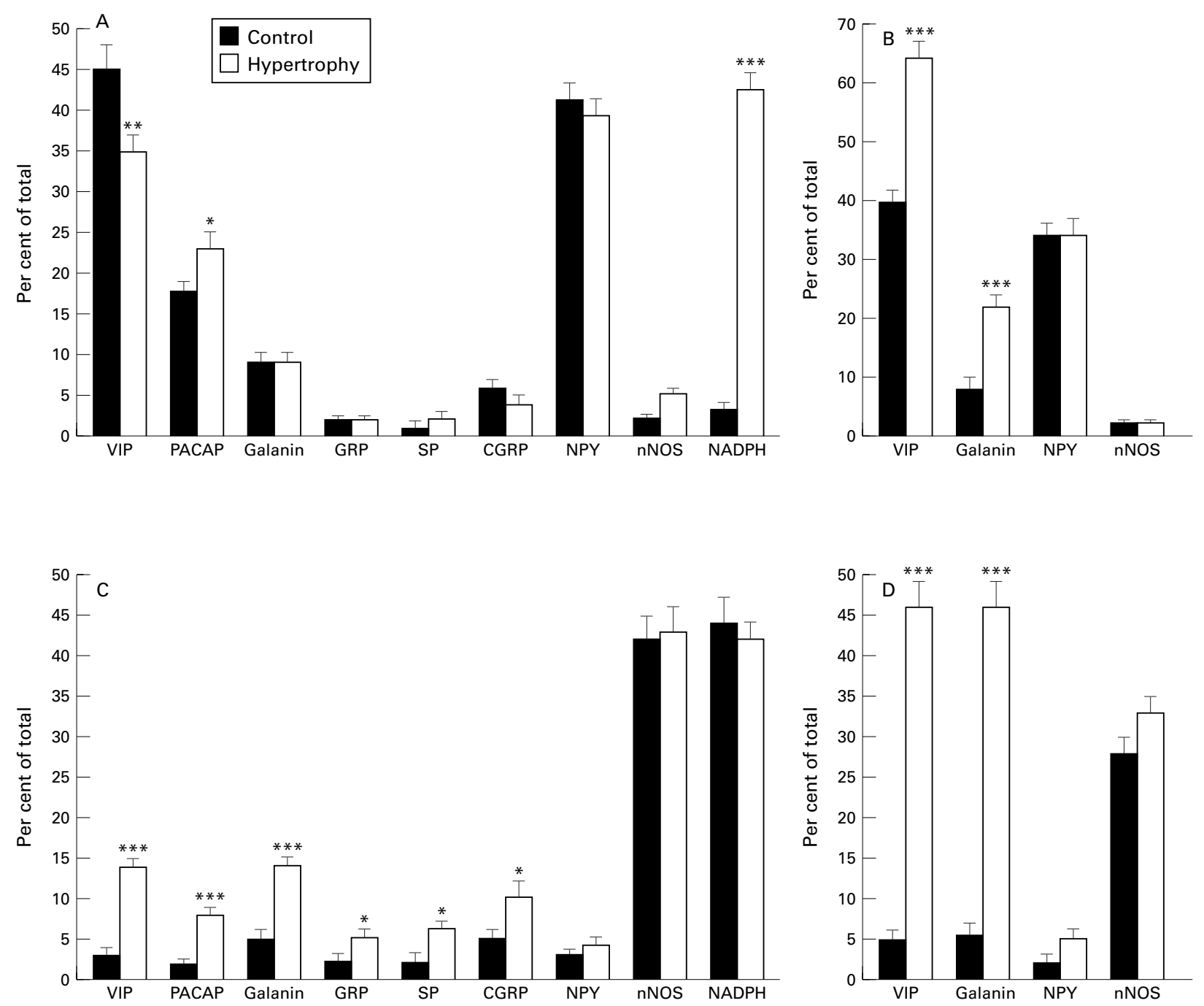

Figure 3 Numbers of VIP, PACAP, galanin, GRP, SP, CGRP, NPY, and nNOS immunoreactive, NADPH diaphorase positive ( $A, C)$, and VIP $m R N A$, galanin $m R N A$, NPY $m R N A$, and $n N O S$ mRNA expressing $(B, D)$ neuronal cell bodies in submucosal $(A, B)$ and myenteric ganglia $(C, D)$ from control and hypertrophic rat ileum. The numbers of positive cell bodies are expressed as the percentage of the total number of cell bodies, established by ethidium bromide staining. Mean (SEM), ${ }^{\star} p<0.05,{ }^{\star *} p<0.01$, ${ }^{\star \star *} p<0.001$.

for NADPH diaphorase activity notably increased (from $3 \%$ to $42 \%$ of total) (figs $1 \mathrm{H}$ and $3 \mathrm{~A}$ ) in hypertrophic ileum.

In control myenteric ganglia nNOS immunoreactive cell bodies were the most frequently occurring population (more than $40 \%$ ); the rest of the neuronal populations each constituted $2-5 \%$ of the total number as studied by immunocytochemistry (fig 3C). In situ hybridisation gave similar figures; the percentages of VIP mRNA, NPY mRNA, and galanin mRNA expressing myenteric nerve cell bodies were $2-5 \%$ (fig $3 \mathrm{D}$ ). In control ileum the percentage of nNOS mRNA expressing myenteric cell bodies was slightly lower ( $28 \%$ of total) (fig 3D) than that of nNOS immunoreactive ones (fig 3C). In hypertrophic ileum several of the myenteric neuronal populations apparently had changed their chemical coding, as examined both by immunocytochemistry (fig 3C) and in situ hybridisation (fig 3D). VIP immunoreactive myenteric neurones increased fivefold (to $14 \%$ of total) (fig 3C) while VIP mRNA expressing neurones increased 10-fold (to $46 \%$ of total) (figs $2 \mathrm{~B}$ and $3 \mathrm{D}$ ). Galanin immunoreactive cell bodies increased threefold (to $14 \%$ of total) (fig 3C) while galanin mRNA expressing neurones showed an almost sevenfold increase (to $46 \%$ of total) (fig 3D). PACAP immunoreactive cell bodies increased fourfold (to $8 \%$ of total), SP immunoreactive cell bodies increased threefold (to 6\%), and GRP and CGRP immunoreactive cell bodies showed a twofold increase (to 5 and $10 \%$ respectively) (fig 3C). The percentages of NPY and nNOS immunoreactive cell bodies (fig 3C) as well as NPY and nNOS mRNA expressing myenteric cell bodies (fig 3D) were unaffected in the hypertrophic ileum. Furthermore, the number of NADPH diaphorase positive neurones was unchanged (fig 3C).

In control rat ileum numerous ICC were visualised, by the c-kit antibodies, within the deep muscular plexus of the circular muscle and between the circular and longitudinal muscle layers (fig 4A). A few ICC were also found intramuscularly, particularly within the circular muscle. The ICC were small with multiple extensions in various directions. In hypertrophic ileum the number of ICC was 

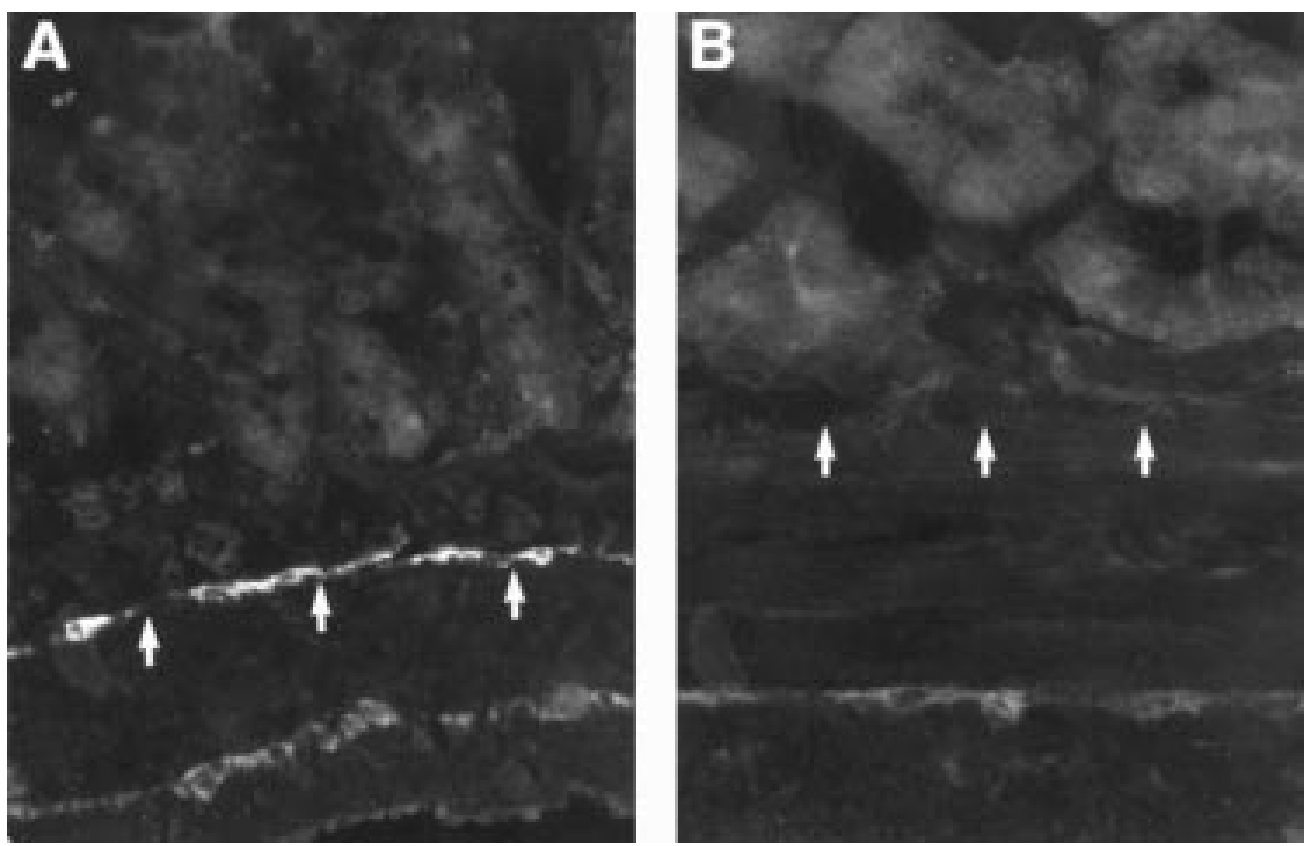

Figure 4 Cryostat sections from rat: control $(A)$ and hypertrophic (B) ileum, showing the presence of ICC using antiserum against c-kit receptor. Numerous ICC can be found within the deep muscular plexus and at the border of longitudinal and circular muscle in the control (A). In the hypertrophic ileum (B) ICC are notably reduced in number, particularly in the deep muscular plexus. The positions of the deep muscular plexus are indicated by arrows. Original magnification $\times 160$.

notably reduced (fig 4B). The deep muscular plexus was almost totally devoid of ICC; none could be found within the muscle layers and only a few around myenteric ganglia and at the border of circular and longitudinal smooth muscle.

\section{Discussion}

Obstruction is a common and severe complication of several disorders, such as inflammatory and neoplastic diseases, in the gastrointestinal tract. Proximal to the obstructed gut segment, hypertrophy and hyperplasia of the smooth muscle accompanied by neoangiogenesis, neoformation of connective tissue matrix, and hypertrophy of both enteric and sensory neurones (dorsal root ganglia) takes place while glial cells remain essentially unaffected (cf Gabella ${ }^{14}$ and Williams et $a l^{17}$ ). The limited growth of intestinal nerve fibres and the reduction of their relative density led to the suggestion by Gabella ${ }^{14}$ that intestinal nerves may not play any major role in the hypertrophic growth of the intestinal muscle. Functionally the hypertrophic segment is overactive with increased force generation and with the ability to generate peristaltic reflexes as effective as in controls. ${ }^{31}$ Thus, irrespective of any direct involvement in the hypertrophic growth of the smooth muscle, the importance of an intact ENS in the hypertrophic segment in order to overcome and compensate for the obstruction is obvious. Hypertrophy of intestinal smooth muscle also develops as a consequence of damage of the myenteric ganglia (as in Chagas' disease or experimentally, for example by treatment with benzalkonium chloride). In these conditions the hypertrophy is often more severe and is accompanied by a considerable dilatation of the affected segment. No coordi- nated peristalsis occurs and continuous filling of the lumen causes increased stretch to the gut wall which is an important stimulus to muscle contraction leading to hypersegmentation. ${ }^{32}$

The present study reports on the up regulation of several neurotransmitters in hypertrophic ileum. VIP, PACAP, and galanin were the neuropeptides most notably affected in the myenteric ganglia. Expansion of the population of enteric VIP expressing neurones has previously been found to occur after axotomy of intramural neurones as well as after colchicine treatment ("chemical axotomy"). ${ }^{11}$ VIP, PACAP, and galanin expression is also up regulated in neurones after isolation by autotransplantation of myenteric ganglia. ${ }^{33}$ The mechanisms behind the neuropeptide up regulation under these conditions are unclear but may reflect lack of target derived factors, such as neurotrophins, due to impaired retrograde transport. The role of neurotrophins in the adult nervous system seems in general to be that of maintenance and survival after injury although other physiological roles cannot be excluded..$^{34}$ In contrast to axotomy and colchicine treatment, hypertrophy due to experimental obstruction of the gut does not involve any direct neuronal damage. It is a gradual process and at its onset mechanical stress due to overdistension of the proximal segment probably plays an important role for the triggering of growth of the musculature. ${ }^{14}$ The ongoing trophic changes in the intestinal wall may alter the environmental conditions of the enteric neurones thus triggering neuronal plasticity, for example, the ability of the enteric neurones to change their expression of neuropeptides. The increased size of the enteric neurones ${ }^{16}$ is probably due to the involvement of growth factors which are likely to be abundant. 
However, very little is known about the initial events, muscular as well as neuronal, that take place during the onset of the hypertrophic growth.

Some neuronal populations within the submucosal ganglia also showed changes in their neurotransmitter content. The percentage of detectable VIP immunoreactive submucosal neurones decreased while the percentage of neurones expressing VIP mRNA increased. This may be explained by a release of VIP that exceeds the synthesis in a population of neurones. Admittedly this is somewhat exceptional, as in neurones an increased mRNA expression is generally accompanied by elevated levels of the translated product. The role for increased VIP release can only be speculated on. Submucous VIP containing neurones project to some extent, in rat small intestine, to the underlying deep muscular plexus in the circular smooth muscle. ${ }^{19}$ Within this plexus numerous ICC are located which possibly constitute a link between submucosal neurones and circular smooth muscle. ${ }^{35}$ Increased release of VIP from submucosal neurones may contribute to the dilatation of the circular smooth muscle. Another perhaps more likely possibility is that VIP contributes to an increased secretion and vasodilatation in the bowel proximal to the obstruction.

A remarkable finding was the increase (from $3 \%$ to $42 \%$ of total) of submucosal neurones showing NADPH diaphorase activity, but lacking nNOS immunoreactive material or expression of nNOS mRNA. This indicates the up regulation of another isoform of NOS, probably the inducible type (iNOS). In the brain iNOS has previously been described to be expressed by neurones (cerebellar granular cells) in response to endotoxin (lipopolysaccharide) and the cytokine interferon $\gamma \cdot{ }^{36}$ Likewise, immunoreactive iNOS increases in regenerating sensory and sympathetic ganglia after a crush lesion. ${ }^{37} \mathrm{NO}$ in the CNS has been suggested to play a role of neuromodulator as well as mediator of neurotoxicity. The latter effect is thought to be executed by $\mathrm{NO}$ produced by iNOS in glial cells. ${ }^{38}$ The finding of iNOS in central neurones after challenge supports a role of iNOS after neuronal damage. In the gut iNOS expression has been found to be minimal in control animals but greatly enhanced by experimentally induced ileitis in the guinea pig. ${ }^{39}$ In that model iNOS was expressed mainly by the epithelium but to some extent also by enteric neurones. In the present study of hypertrophic ileum we did not notice any increased NADPH diaphorase activity in the epithelium, probably reflecting a much lower grade of inflammation than in acute ileitis. However, the putative location of iNOS in submucosal neurones, but not within the epithelium, suggests that the main function of an increased neuronal NO production by iNOS is not primarily in the defence against microorganisms but rather as a modulator of neurotransmission or mediator of neuronal damage.

In addition to changes in the set of neurotransmitters of enteric neurones we report on a notable decrease in the number of ICC in hypertrophic ileum. The functional significance of this is unclear but as strong evidence suggests that ICC are involved in the generation of slow waves (for a review see Sanders ${ }^{7}$ ) the reduced number of ICC may be related to the decreased number of peristaltic waves generated by the hypertrophic segment compared with the control. ${ }^{31}$ The reasons for the loss of ICC in hypertrophic ileum are not obvious; however, these cells have been reported to be extraordinarily sensitive to hypoxia, ${ }^{40}$ a condition that might accompany the hypertrophy. A lack of interstitial cells has previously been reported to occur in hypertrophic pyloric stenosis. ${ }^{23}$

The present study shows that after partial obstruction of the ileum the enteric neurones in the proximally located hypertrophic segment display remarkable plasticity in terms of a changed expression of a number of neuromessengers. The mechanisms behind this are poorly understood. Studies on the expression of growth factors for smooth muscle and neurones as well as their receptors within the gut would probably provide interesting insights into the complex field of regulation and maintenance of gastrointestinal function.

This work was funded by the Swedish Medical Research Council (project numbers 12X-4499 and 04X-8268), Påhlsson, Bergwall, T Zoega, Viberg, and Crafoord Foundations.

1 Ekblad E, Håkanson R, Sundler F. Microanatomy and chemical coding of peptide-containing neurons in the digestive tract. In: Daniel EE, ed. Neuropeptide function in the gastrointestinal tract. Boca Raton, Florida: CRC Press, 1991:131-79.

2 Podolsky DK. Peptide growth factors in the gastrointestinal tract. In: Johnson LR, ed. Physiology of the gastrointestinal tract. New York: Raven Press, 1994:129-67.

3 Furness JB, Young HM, Pompolo S, et al. Plurichemical transmission and chemical coding of neurons in the digestive tract. Gastroenterology 1995;108:554-63.

4 Wood JD. Physiology of the enteric nervous system. In: Johnson LR, ed. Physiology of the gastrointestinal tract, Volume 1, son LR, ed. Physiology of the gastrointestinal tract,

5 Gershon MD, Kirchgessner AL, Wade PR. Functional anatomy of the enteric nervous system. In: Johnson LR, ed. anatomy of the enteric nervous system. In: Johnson LR, ed.
Physiology of the gastrointestinal tract, Volume 1, 3rd edition. Physiology of the gastrointestinal tract, Volum

6 Kobayashi S. The centenary of the problem of the interstitial cells of Cajal. Acta Anat Nippon 1996;71:629-37.

7 Sanders KM. A case for interstitial cells of Cajal as pacemakers and mediators of neurotransmission in the gastrointestinal tract. Gastroenterology 1996;111:492-515.

8 Komuro T, Zhou D-S. Anti-c-kit protein immunoreactive cells corresponding to the interstitial cells of Cajal in the guinea pig intestine. F Auton Nerv Syst 1996;61:169-74.

9 Hökfelt T, Zhang X, Wiesenfeld-Hallin Z. Messenger plasticity in primary sensory neurons following axotomy and its functional applications. Trends Neurosci 1994;17:22-30.

10 Saffrey MJ, Burnstock G. Growth factors and the development and plasticity of the enteric nervous system. $\mathcal{F}$ Auton Nerv Syst 1994;49:183-96.

11 Ekblad E, Mulder H, Sundler F. Vasoactive intestinal peptide expression in enteric neurons is upregulated by peptide expression in enteric neurons is upregulated by
both colchicine and axotomy. Regul Peptides 1996;63:11321.

12 Earlam RJ. Ganglion cell changes in experimental stenosis of the gut. Gut 1971;12:393-8.

13 Gabella G. Hypertrophy of intestinal smooth muscle. Cell Tissue Res 1975;163:199-214

14 Gabella G. Hypertrophy of visceral smooth muscle. Anat Embryol 1990;182:409-24.

15 Williams TH, Jew JY. Neuronal responses to gut hypertrophy. F Auton Nerv Syst 1991;33:204-6.

16 Gabella G. Size of neurons and glial cells in the intramural ganglia of the hypertrophic intestine of the guinea pig. $\mathcal{F}$ Neurocytol 1984;13:73-84.

17 Williams TH, Zhang M-Q, Jew JY. Hypertrophy of rat sensory ganglion neurons following intestinal obstruction. Gastroenterology 1993;105:8-14.

18 Jew JY, Williams TH, Gabella G, et al. The intestine as a model for neuronal plasticity. Arch Histol Cytol 1989;52: 167-80.

19 Ekblad E, Winther C, Ekman R, et al. Projections of peptide-containing neurons in rat small intestine. Neuroscience 1987;20:169-88. 
20 Ekblad E, Ekman R, Håkanson R, et al. Projections of peptide-containing neurons in rat colon. Neuroscience 1988:27:655-74.

21 Ekblad E, Alm P, Sundler F. Distribution, origin and projections of nitric oxide synthase-containing neurons in gut and pancreas. Neuroscience 1994;63:233-48.

22 Sundler F, Ekblad E, Absood A, et al. Pituitary adenylate cyclase activating peptide: a novel vasoactive intestinal peptide-like neuropeptide in the gut. Neuroscience 1991;46: 439-54.

23 Vanderwinden J-M, Liu H, De Laet M-H, et al. Study of the interstitial cells of Cajal in infantile hypertrophic pyloric stenosis. Gastroenterology 1996;111:279-88.

24 Bredt DS, Hwang PM, Glatt CE, et al. Cloned and expressed nitric oxide synthase structurally resembles cytochrome P-450 reductase. Nature 1991;351:714-18.

25 Nishizawa M, Hayakawa Y, Yanaihara N, et al. Nucleotide sequence divergence and functional constraint in VIP precursor mRNA evolution between human and rat. FEBS Lett 1985;183:55-9.

26 Larhammar D, Ericsson A, Persson H. Structure and expression of the rat neuropeptide Y gene. Proc Natl Acad expression of the rat neurop

27 Kaplan LM, Spindel ER, Isselbacher KJ, et al. Tissuespecific expression of the rat galanin gene. Proc Natl Acad Sci USA 1988;85:1065-9.

28 Mulder H, Uddman R, Moller K, et al. Pituitary adenylate cyclase activating polypeptide (PACAP) expression in sensory neurons. Neuroscience 1994;63:307-12.

29 Hope B, Michael GJ, Knigge KM, et al. Neuronal NADPH diaphorase is a nitric oxide synthase. Proc Natl Acad Sci USA 1991;88:2811-14

30 Schmued LC, Swanson LW, Sawchenko PE. Some fluorescent counterstains for neuroanatomical studies. $\mathcal{F}$ Histochem Cytochem 1982;30:123-8.
31 Schultze-Delrieu K, Brown B, Herman B, et al. Preservation of peristaltic reflex in hypertrophied ileum of guinea pig. Am 7 Physiol 1995;269:G49-59.

32 Smith B. The myenteric plexus in man. In: The neuropathology of the alimentary tract. London: Edward Arnold (Publishers) Ltd, 1972:12-16.

33 Sundler F, Ekblad E, Hannibal J, et al. Pituitary adenylate cyclase-activating peptide in sensory and autonomic ganglia: localization and regulation. In: Arimura A, Said SI, eds. VIP, PACAP and related peptides. Ann N Y Acad Sci 1996;85:410-28.

34 Levi-Montalcini R, Skaper SD, Dal Toso R, et al. Nerve growth factor: from neurotrophin to neurokine. TINS 1996;19:514-20.

35 Burns AJ, Lomax AEJ, Torihashi S, et al. Interstitial cells of Cajal mediate inhibitory transmission in the stomach. Proc Natl Acad Sci USA 1996;93:12008-13.

36 Minc-Golomb D, Tsarfaty I, Schwartz JP. Expression of inducible nitric oxide synthase by neurons following expoure to endotoxin and cytokine. Br f Pharmacol 1994;112: $720-2$.

37 Magnusson S, Alm P, Kanje M. Inducible nitric oxide synthase increases in regenerating rat ganglia. Neuroreport thase increases in

38 Moncada S, Palmer RMJ, Higgs EA. Nitric oxide: physiology, pathology and pharmacology. Pharmacol Rev 1991;443:109-42.

39 Miller MJS, Thompsom JH, Zhang X-J, et al. Role of inducible nitric oxide synthase expression and peroxynitrite formation in guinea pig ileitis. Gastroenterology 1995;109: 1475-83.

40 Christensen J, Rick GA. Interstitial cells of Cajal in the rat colon are damaged by mild hypoxia. F Auton Nerv Syst 1994;48:175-80. 